\title{
Peningkatan Hasil Belajar Matematika Materi Volume Bangun Ruang Melalui Model Inkuiri Terbimbing Menggunakan Media Manipulatif Siswa Kelas V SDN 44 Bengkulu Tengah
}

\section{Sunyiati}

SD Negeri 44 Bengkulu Tengah sunyitriantoro@gmail.com

\begin{abstract}
This research aims to improve the activities and results of learning mathematics using the Guided Inquiry model for $V$ grade students of SDN 44 Bengkulu Tengah. This type of research is a classroom action research conducted in two cycles. The subjects of this study were teachers and students of grade V SDN 44 Bengkulu Tengah. The research instrument used the teacher activity observation sheet, student activity and learning results tests. The data analysis technique uses arithmetic mean and the percentage of learning completeness. The results showed: 1) teacher activity in the first cycle obtained an average of 3.15 increased to the second cycle obtained an average of $3.78,2)$ student activity in the first cycle obtained an average of 3.21 and increased in the second cycle to $3,71,3)$ The learning result in the first cycle obtained an average of 61.87 with $62.50 \%$ completeness learning, increased in the second cycle to 78.75 with $81.25 \%$ learning completeness. The conclusion of this study that the use of Guided Inquiry model using manipulative media can increase the activity and learning result of $V$ grade students of SDN 44 Bengkulu Tengah.
\end{abstract}

Keywords : Guided Inquiry, Learning Result, Student Activity, Mathematics

\begin{abstract}
Abstrak
Penelitian ini bertujuan untuk meningkatkan aktivitas dan hasil belajar matematika menggunakan model Inkuiri Terbimbing siswa kelas V SDN 44 Bengkulu Tengah. Jenis penelitian ini adalah penelitian tindakan kelas yang dilakukan sebanyak dua siklus. Subyek penelitian ini adalah guru dan siswa kelas V SDN 44 Bengkulu Tengah. Instrumen penelitian menggunakan lembar observasi aktivitas guru, aktivitas siswa dan tes hasil belajar. Teknik analisis data mengunakan rata-rata hitung dan persentase ketuntasan belajar. Hasil penelitian menunjukkan: 1) aktivitas guru pada siklus pertama diperoleh rata-rata 3,15 meningkat ke siklus kedua diproleh rata-rata $3,78,2$ ) aktivitas siswa pada siklus pertama diperoleh rata-rata 3,21 danmeningkat pada siklus kedua menjadi 3,71, 3)Hasil belajar pada siklus I diproleh rat-rata 61,87 dengan ketuntasan belajar $62,50 \%$, meningkat pada siklus II menjadi 78,75 dengan ketuntasan belajar $81,25 \%$. Kesimpulan dari penelitian ini penggunaan
\end{abstract}


model Inkuiri Terbimbing menggunakan media manipulatif dapat meningkatkan aktivitas dan hasil belajar matematika siswa kelas $\mathrm{V}$ SDN 44 Bengkulu Tengah.

Kata kunci : Model Inkuiri Terbimbing, Media media manipulatif, Aktivitas Belajar, Hasil Belajar, Pembelajaran Matematika

\section{Pendahuluan}

Matematika merupakan salah satu bidang studi yang berkaitan erat dengan kehidupan manusia, hampir setiap aktivitas manusia terkait dengan Matematika. Matematika sangat berguna bagi kehidupan manusia untuk memecahkan masalah yang terjadi dalam kehidupan sehari-hari. Melalui matematika siswa terlatih berpikir secara logis, analitis dan sistematis. Sesuai dengan pendapat Karso (2007) menjelaskan bahwa dengan Matematika dapat membentuk pola pikir orang yang mempelajarinya menjadi pola pikir matematis yang sistematis, logis, dan kritis.

Matematika merupakan ilmu yang kajian objeknya bersifat abstrak. Objek Matematika yang abstrak membuat siswa sulit dalam mempelajarinya. Tidak hanya siswa yang kesulitan, guru juga mengalami kesulitan dalam mengajarkan Matematika terutama dalam menanamkan konsep matematika. Oleh karena itu dalam pembelajaran Matematika di SD sebaiknya disesuaikan dengan taraf mental siswa SD. Menurut Jean Piaget dalam Heruman (2007), bahwa perkembangan intelektual anak SD berada pada fase operasional konkrit,artinya pada tahap ini anak lebih mudah menerima dan mempelajari matematika melalui objek yang bersifat nyata. Sesuai teori Bruner dalam Karso (2007), pembelajaran Matematika itu diberikan secara bertahap mulai dari hal-hal yang bersifat nyata (konkrit), semi konkret kemudian ke abstrak. Dalam pembelajaran Matematika guru dapat menggunakan benda-benda konkrit yang ada dilingkungan sekitar

Salah satu tujuan dari pembelajaran Matematika di sekolah dasar yakni pemahaman konsep, menjelaskan keterkaitan antar konsep dan mengaplikasikan konsep Matematika tersebut dalam kehidupan sehari-har Depdiknas, 2006). Sejalan dengan pendapat Heruman (2007), menyatakan bahwa tujuan akhir dari pembelajaran Matematika di SD adalah membuat siswa terampil dalam menggunakan berbagai konsep Matematika di kehidupan sehari-hari.

Berdasarkan pengalaman mengajar selama peneliti menjadi guru terdapat permasalahan sebagai berikut: 1) dalam mengajarkan matematika hanya berorientasi pada buku, sehingga siswa sering kurang memahami materi yang dipelajari, 2) metode mengajar masih monoton,yaitu ketika mengajarkan matematika langsung memberi contoh soal dan menjelaskan cara menyelesaikan sesudah itu diberi latihan dan jika soal latihan berbeda dengan contoh siswa tidak bisa mengerjakan, 3)dalam belajar matematika jarang menggunakan alat peraga untuk menanamkan kosep, 4)setiap siswa mengerjakan soal matematika jarang dibimbing, 5) hasil ulangan Matematika rendah, rata-rata nilai siswa kelas yaitu 54,4 dengan ketuntsan belajar 62,50\%, dengan rincian 7 siswa sudah mencapai KKM dan 9 orang belum mencapai KKM.

Berdasarkan permasalahan tersebut, peneliti berdiskusi dengan teman sejawat dan kepala sekolah untuk mencari solusi perbaikan pembelajaran. Hasil diskusi disepakati dalam pembelajaran matematika menggunakan model inkuiri 
terbimbing. Inkuiri terbimbing merupakan salah satu jenis pembelajaran dengan pendekatan penemuan. Inkuiri terbimbing sangat cocok dengan karakteristik anak SD, karena dalam proses pembelajaran masih memerlukan bimbingan agar kegiatan pembelajaran lebih terarah. Adapun langkah-langkah model inkuiri terbimbing sebagai berikut: 1) merumuskan masalah,siswa diperikan permasalahan dan dimotivasi mencari jawabanny, 2)Observasi, siswa melakukan eksplorasi untuk menemukan jawaban, 3)Menganalisi, siswa diberi kesempatan menganalisis kebenaran jawaban dan menyusun laporan, 4)Mengkomunikasikan, siswa diberi kesempatan melaporkan hasil penemuan kepada teaman (Trianto,2011).

Menurut Jauhar (2011), menyatakan bahwa pada proses pembelajaran, bimbingan yang guru berikan kepada siswa berupa pertanyaan-pertanyaan dan diskusi mulitiarah yang mengiring siswa agar bisa menemukan dan memahami konsep yang dipelajarinya, sehingga hasil belajar lebih baik. Hal ini sesuai dengan penelitian Astuti (2016), hasil penelitian ini menyebutkan bahwa penerapan model inkuiri terbimbing dengan media konkret dapat meningkatkan hasil belajar matematika siswa pada materi bangun datar pada siswa kelas VB SD Negeri 1 Sidoharum.

Pembelajaran menggunakan model inkuiri terbimbing, memberikan peluang kepada siswa untuk melakukan aktivitas untuk menemukan konesp. Hal ini didukung Bruner (dalam Anam,2015), yang mengemukakan dengan pembelajaran inkuiri terbimbing siswa akan mudah memahami konsep dan mengemukakan ideide secara lebih baik.

Untuk memudahkan siswa menemukan dan memahami konep, dalam pembelajaran menggunakan media manipulatif. Menurut Muhsetyo (2014), media manipulatif adalah bahan yang dapat dimanipulasikan dengan tangan, yakni bisa diputar, dipegang, dibalik, dipindah, atau dipotong-potong. Media manipulatif yang cocok untuk membatu menemukan konsep pada materi . Media manipulatif dapat membuat pembelajaran lebih aktif dan dapat membuat hasil belajar siswa meningkat. Hal ini didukung oleh penelitian yang dilakukan oleh Parti (2016), hasil penelitian menunjukkan bahwa penggunaan media benda manipulatif dapat meningkatkan kualitas pembelajaran yang dilakukan guru dan meningkatkan ketuntasan belajar peserta didik kelas III SD Negeri Doyomulyo. Ketuntasan belajar meningkat dari $66,66 \%$ pada siklus I meningkat menjadi $88,88 \%$ pada siklus II.

\section{Metode}

Jenis penelitian yang digunakan yang digunakan adalah penelitian tindakan kelas (clasroom Action research), yang terdiri dari dua siklus. Setiap sikklus terdiri dari tahap perencanaan, tindakan, pengamatan dan refleksi. Menurut Wardani (2007), penelitian tindakan kelas adalah penelitian yang dilakukan guru di dalam kelas melalui refleksi diri dengan tujuan untuk memperbaiki kinerja guru sehingga hasil belajar siswa meningkatPenelitian ini untuk membantu memecahkan masalah dan memperbaiki proses pembelajaran matematika secara reflekstif dan kolaboratif. Subyek penelitian ini adalah guru dan siswa kelas V SDN 44 Bengkulu Tengah. Jumlah siswa kelas V yaitu 16 orang yang terdiri 11 perempuan dan 6 laki-laki

Instrumen yang digunakan dalam penelitian ini adalah lembar observasi aktivitas guru dan aktivitas siswa serta lembar tes. Lembar observasi aktivitas guru 
dan siswa digunakan untuk melihat aktivitas selama proses pembelajaran matematika berlangsung. Sedangkan lembar tes digunakan untuk mengukur keberhasilan siswa dalam menguasai konsep atau hasil belajar. Teknik analisis lembar observasi aktivitas guru dan siswa menggunakan perhitungan rata-rata, sedangkan untuk mengolah data hasil tes mengunakan perhitungan rata-rata dan persentase ketuntasan belajar.

\section{Hasil Penelitian}

\section{Hasil Penelitian Siklus I}

Pembelajaran siklus I membahas tentang volume kubus dan balok. Langkahlangkah penelitian dilakukan sebagai berikut:

a. Tahap perencanaan

Dalam perencanaan siklus I meliputi : 1)menyusun RPP menggunakan model Inkuiri terbimbing, 2)meyiapkan media manipulaif berupa model kubus dan balok transparan, kubus satuan 3) menyusun Lembar Kerja Peserta Didik (LKPD), 4)menyiapkan lembar observasi aktivitas guru dan siswa dan 5) menyiapkan soal evaluasi.

b. Pelaksanaan tindakan

Guru mengajarkan konsep volume kubus dan balok dengan langkahlangkah sebagai berikut:

1)Merumskan masalah, pada tahap ini guru memberikan permasalahan tentang volume bangun ruang kubus dan balok dengan cara memotivasi siswa diminta mengamati kotak kue Siip Nabati yang masih penuh berisi kue, selanjutnya guru dan siswa melakukan Tanya jawab yang diarahkan ke permasalahan volume bangun ruang , 2 )Melakukan observasi, siswa dibentu $\mathrm{k}$ menjadi empat kelompok. Setiap kelompok diberi tugas mengerjakan LKPD untuk menemukan konsep volume bangun ruang kubus dan balok dengan menggunakan media manipulative berupa model kubus dan balok transparan, kubus-kubus satuan, siswa dibimbing menemukan konsep volume kubus dan balok, 3) Menganalisis dan menyajikan hasil, pada tahap ini setiap kelompok dibimbing melakukan percobaan atau mendemonstrasikan cara menemukan konsep volume kubus dan balok menggunakan media manipulatif sampai menemukan rumus volume bangun kubus dan balok 4) Mengkomunikasikan, pada tahap ini setiap kelompok diminta melaporkan hasil diskusi dan kelompok lain menanggapi. Setelah setiap kelompok melaporkan hasil diskusi, guru memberikan pemantapan materi. Kegiatan dilanjutkan membimbing siswa menyimpulkan materi dan mengerjakan soal tes evaluasi.

c. Tahap observasi

Observasi ini untuk melihat proses pembelajaran yang dilakukan guru di kelas.Sebagai observer yaitu teman sejawat dan kepala sekolah dengan menggunakan lembar observasi aktivitas guru dan siswa. Selama proses pempelajaran observer mencatat aktivitas guru meliputi: 1) membimbing siswa merumuskan permasalahan, 2)memfasilitasi siswa melakukan Tanya 
jawab, 3) membimbing siswa berdiskusi mengerjakan LKPD,4) Membimbing siswa menggunakan media manipulative untuk menemukan konsep, 5) Membimbing siswa membuat laporan hasil diskusi,6)Membimbing siswa melaporkan hasil diskusi dan 7)membimbing siswa menarik kesimpulan. Selanjutnya aktivitas siswa meliputi:1) Merumuskan masalah,2) melakukan Tanya jawab,3)melakukan diskusi kelompok,4) Menggunakan media untuk menemukan konsep,5)Menyusun laporan hasil diskusi,6) melaporkan hasil diskusi, 7) membuat kesimpulan materi pelajaran

Hasil pengolahan data aktivitas guru disajikan pada tabel berikut:

Tabel 1. Hasil Observasi Aktivitas Guru Siklus I

\begin{tabular}{cccc}
\hline Materi & Observer & Skor & Kriteria \\
\hline volume kubus & I & 3,07 & Baik \\
\cline { 2 - 4 } dan balok & II & 3,14 & Baik \\
\hline Rata -rata & & 3,15 & Baik \\
\hline
\end{tabular}

Adapun hasil aktivitas siswa disajikan pada tabel berikut:

Tabel 2. Hasil Observasi Aktivitas Siswa Siklus I

\begin{tabular}{|c|c|c|c|}
\hline Materi & Observer & Skor & Kriteria \\
\hline \multirow{2}{*}{$\begin{array}{c}\text { Volume kubus } \\
\text { dan balok }\end{array}$} & $\mathrm{I}$ & 3,14 & Baik \\
\hline & II & 3,28 & Baik \\
\hline \multicolumn{2}{|c|}{ Rata-rata } & 3,21 & Baik \\
\hline
\end{tabular}

Di akhir pembelajaran siswa diberikan soal tes untuk mengetahui tingkat keberhasilan proses pembelajaran siklus I. Hasil analisis pengolahan data hasil belajar siswa siklus I disajikan pada tabel berikut:

Tabel 3. Hasil Belajar Siswa Siklus I

\begin{tabular}{lc}
\hline \multicolumn{1}{c}{ Uraian } & Hasil \\
\hline Jumlah siswa yang ikut tes & 16 \\
\hline Skor Terendah & 40 \\
\hline Skor Tertinggi & 80 \\
\hline Jumlah skor & 99 \\
\hline Rata-rata skor & 61,87 \\
\hline Jumlah siswa yang tuntas & 10 \\
\hline Jumlah siswa yang tidak tuntas & 6 \\
\hline Persentase ketuntasan & $62,50 \%$ \\
\hline Keterangan & Belum tuntas \\
\hline
\end{tabular}

\section{d. Refleksi}

Pada tahap refleksi ini Kepala Sekolah, teman sejawat dan peneliti melakukan diskusi untuk mengetahui kelebihan dan kekurangan selama proses pembelajaran. Dari hasil diskusi ditemukan kelebihan pembelajaran siklus I, yaitu : 1) guru sudah membimbing siswa melakukan Tanya jawab dengan baik, 2) guru membimbing siswa melaporkan hasil diskusi dengan 
baik, 3)siswa sudah melaporkan hasil diskusi dengan runtus dan sistimatis. Adapun kelemahan, sebagai berikut: 1) guru belum memberikan bimbingan dalam merumuskan masalah secara maksimal,2) guru belum membimbing siswa dalam menggunakan media manipulatif untuk menemukan konsep,3) ketika diskusi lebih didominasi siswa yang pintar dan siswa lain ribut, 4) sebagian siswa masih pasip dan 5) Nilai rata-rata masih rendah yaitu 61,87 dengan ketuntasan belajar $62,50 \%$

\section{Hasil Penelitian siklus II}

a. Tahap perencanaan

Perencanaan yang dilakukan pada siklus ke II dilakukan dengan memperhatikan kelemahan siklus I .Adapan perencanaan yang dilakukan guru yaitu: 1) menyusun RPP menggunakan model Inkuiri terbimbing dengan materi soal cerita atau pemecahan masalah yang berkaitan dengan volume kubus dan balok, 2) membuat Lembar Kerja Peserta Didik (LKPD), 3) menyiapkan lembar obsevasi aktivitas guru,4) menyiapkan lembar observasi siswa dan 5)menyiapkan tes evaluasi.

b. Tahap Tindakan

Guru mengajarkan materi soal cerita atau pemecahan masalah dalam kehidupan sehari-hari yang berkaitan dengan volume kubus dan balok dengan langkah-langkah sebagai berikut: 1)Merumskan masalah , pada tahap ini guru memberikan soal cerita tentang permasalahan dalam kehidupan sehari-hari yang berkaitan dengan volume kubus dan balok, selanjutnya guru dan siswa melakukan Tanya jawab yang diarahkan siswa dapat memahami isi soal cerita dan prosedur menyelesaikan soal cerita , 2 )Melakukan observasi, siswa dibentuk menjadi empat kelompok . Setiap kelompok diberi tugas mengerjakan LKPD untuk menyelesaikan soal cerita dengan prosedur yang benar, 3) Menganalisis dan menyajikan hasil, pada tahap ini setiap kelompok dibimbing melakukan pengecekan hasil menyelesaikan LKPD, 4) Mengkomunikasikan, pada tahap ini setiap kelompok diminta melaporkan hasil diskusi dan kelompok lain menanggapi. Setelah setiap kelompok melaporkan hasil diskusi, guru memberikan pemantapan materi. Kegiatan dilanjutkan membimbing siswa menyimpulkan materi dan mengerjakan soal tes evaluasi.

c. Tahap observasi

Pada tahap ini kepala sekolah dan teman sejawat mengamati aktivitas guru dan siswa selama proses pembelajaran. Hasil pengolahan data aktivitas guru Siklus II disajikan pada tabel berikut :

Tabel 4. Hasil Observasi Aktivitas Guru Siklus II

\begin{tabular}{cccc}
\hline Materi & Observer & Skor & Kriteria \\
\hline \multirow{2}{*}{ Soal cerita } & I & 3,71 & Sangat Baik \\
\cline { 2 - 4 } & II & 3,85 & Sangat Baik \\
\hline Rata - rata & 3,78 & Sangat Baik \\
\hline
\end{tabular}

Adapun hasil pengolahan data aktivitas siswa siklus II disajikan pada tabel berikut: 
Tabel 5. Hasil Observasi Aktivitas Siswa Siklus II

\begin{tabular}{|c|c|c|c|}
\hline Materi & Observer & Skor & Kriteria \\
\hline \multirow{2}{*}{ Soal cerita } & $\mathrm{I}$ & 3,71 & Sangat Baik \\
\hline & II & 3,71 & Sangat Baik \\
\hline \multicolumn{2}{|c|}{ Rata-rata } & 3,71 & Sangat Baik \\
\hline
\end{tabular}

Di akhir pembelajaran siswa diberikan soal tes untuk mengetahui tingkat keberhasilan proses pembelajaran siklus II. Hasil analisis pengolahan data hasil belajar siswa siklus II disajikan pada tabel berikut:

Tabel 6. Hasil Belajar Siswa Siklus II

\begin{tabular}{lc}
\hline \multicolumn{1}{c}{ Uraian } & Hasil \\
\hline Jumlah siswa yang ikut tes & 16 \\
\hline Skor Terendah & 60 \\
\hline Skor Tertinggi & 90 \\
\hline Jumlah skor & 1.260 \\
\hline Rata-rata skor & 78,75 \\
\hline Jumlah siswa yang tuntas & 13 \\
\hline Jumlah siswa yang tidak tuntas & 3 \\
\hline Persentase ketuntasan & $81,25 \%$ \\
\hline Keterangan & Tuntas \\
\hline
\end{tabular}

d. Tahap Refleksi

Peneliti, guru kelas dan kepala sekolah melakukan diskusi untuk menemukan kelebihan dan kekuranga. Kelebihan pada siklus II, yaitu 1) siswa sudah terlibat aktif memahami masalah,2)siswa antusias dan semangat melakukan tanya jawab, 3)siswa sudah terlibat aktif berdiskusi untuk memecahkan masalah, 4) Siswa kreatif masalah,5) siswa sudah berani menanggapi hasil diskusi kelompok lain dan 5) rata-rata nilai dan ketuntasan belajar sudah tercapai. Adapun kelemahannya masih 3 siswa yang mendapat nilai kurang dari KKM dan perlu bimbingan secara khusus.

\section{Pembahasan}

Pelaksanaan pembelajaran menggunakan model inkuiri terbimbing menggunakan media manipulatif terdiri dari empat tahap yaitu: tahap pertama merumuskan masalah, pada tahapan ini siswa dibimbing oleh guru untuk merumuskan permasalahan yang ditampilkan guru menggunakan media manipulatif model bangun ruang. Siswa terlihat antusias dan serius mengamati model bngun ruang yang ditampilkan guru. Saat Tanya jawab siswa sudah mulai berani bertanya dan aktif menjawab pertanyaan-pertanyaan yang diajukan oleh guru. Di samping itu siswa sudah mulai tertarik untuk mempelajari dan memahami materi. Sesuai pendapat Anam (2015), keterlibatan siswa dalam setiap proses pembelajaran merupakan bagian terpenting untuk mengembangkan kemampuan siswa karena proses tersebut melibatkan kegiatan mental-intelektual dan sosialemosional siswa.

Tahap Kedua mengamati atau melakukan eksplorasi pada tahap ini setiap kelompok diberi kesempatan memanipulasi alat peraga model kubus, balok dan 
kubus satuan untuk menemukan volume bangun kubus dan balok. Guru memberikan bimbingan dan pengarahan cara menggunakan media untuk menemukan konsep. Siswa terlibat aktif dan kreatif menggunakan media untuk menemukan konsep volume kubus dan balok. Sesuai pendapat Kusmana (2010) mengemukakan pembelajaran menggunakan model inkuiri dapat meningkatkan potensi intelektual siswa, pembelajaran berpusat pada siswa dan siswa dapat belajar bagaimana menemukan konsep

Tahap ketiga menganalisis data, Siswa dibimbing untuk menanalisis hasil diskusi untuk mengecek kebenaran dari hasil eksplorasi. Siswa juga dibimbing menemukan rumus dengan benar dan mengaplikasikan untuk memecahkan masalah dalam kehidupan sehari-hari yang berkaitan dengan volume kubus dan balok. Siswa mendapatkan pengalaman belajar yang menarik, menyenangkan dan pembelajaran menjadi bermakna. Sesuai pendapat Sanjaya (2012) menyatakan bahwa kelebihan pembelajaran model inkuiri terbimbing menjadikan pembelajaran menjadi bermakna dan siswa dapat belajar sesuai dengan gaya belajarnya.

Tahap keempat mengkomunikasikan, pada tahap ini tingkat siswa mulai percaya diri dan berani melaporkan hasil diskusi. Siswa juga aktif menanggapi hasil diskusi dari kelompok lain.

Hasil observasi aktivitas guru pada siklus I diperoleh rata-rata skor 3,15 dengan kategori baik. Pada siklus I ini guru masih kurang membimbing siswa pada saat menggunakan alat peraga dan menganalisis data, guru juga masih kurang dalam membimbing kelompok, hal ini terlihat saat tahap eksplorasi, guru hanya terfokus pada beberapa kelompok saja. Setelah diperbaiki pada siklus II skor aktivitas guru meningkat menjadi skor 3,78 kategori sangat baik.

Hasil aktivitas siswa siklus I diperoleh rata-rata skor 3,21 dengan kategori baik. Pada saat pembelajaran siswa kurang berani bertanya. Ketika diskusi belum seluruh siswa terlibat aktif. Pada siklus II siswa mulai semangat, antusias dan berani bertanya dan berpendapat, Siswa juga mulai kreatif ketika melakukan eksplorasi dan analisis data, sehingga skor rata-rata aktivitas siswa meningkat menjadi 3,71 kategori sangat baik.

Hasil belajar dari nilai rata-rata tes siklus I sebesar 61,87 dengan ketuntasan belajar sebesar $62,50 \%$, meningkat pada siklus II menjadi 78,75 dengan ketuntasan belajar $81,25 \%$. Hal ini sesuai dengan hasil penelitian Krismayeni (2016) hasil penelitian menunjukkan bahwa penerapan model pembelajaran Inkuiri Terbimbing dapat meningkatkan hasil belajar Matematika siswa kelas V semester Genap tahun pelajaran 2015/2016 di SD N 4 Selat. Hal tersebut dilihat dari hasil belajar Matematika siswa adalah 61.8\% (kategori rendah) dan meningkat pada siklus II menjadi 74\% (kategori sedang).

\section{Kesimpulan}

Berdasarkan hasil penelitian dapat disimpulkan, sebagai berikut: 1)Penerapan model Inkuiri terbimbing menggunakan media manipulatif dapat meningkatkan aktivitas guru, yang dibuktikan perolehan nilai rata- rata skor siklus I, yaitu 3,15 berada pada kategori baik, meningkat pada siklus II menjadi 3,78 pada kategori sngat baik, 2)Penerapan model Inkuiri terbimbing menggunakan media manipulatif dapat meningkatkan aktivitas siswa yang dibuktikan dengan perolehan rata-rata aktivitas siswa siklus I, yaitu 3,21 pada katagori baik, meningkat pada 
siklus II menjadi 3,71 pada katagori sangat baik, 3) Penerapan model Inkuiri Terbimbing menggunakan media manipulatif dapat meningkatkan hasil belajar matematika, pada siklus I diperoleh rat-rata 61,87 dengan ketuntasan belajar $62,50 \%$ meningkat padsa siklus II menjadi 78,75 dengan ketuntasan belajar 81,25\%

\section{Saran}

Berdasarkan kesimpulan hasil penelitian maka disarankan :

1. Guru sebaiknya dalam pembelajaran matematika menggunakan model inkuiri terbimbing menggunakan media manipulatif karena dapat memudahkan siswa menemukan dan memahami konsep shingga pembelajaran menjadi bermakna

2. Guru sebaiknya dalam pembelajaran matematika menggunakan model inkuiri terbimbing karena dapat meningkatkan kualitas pembelajaran

\section{Referensi}

Anam, K., (2015), Pembelajaran Berbasis Inkuiri Metode dan Aplikasi, Yogyakarta: Pustaka Pelajar.

Astuti, E. R., Joharman, J., \& Suripto, S. (2017). Penerapan Model Inkuiri Terbimbing Dengan Media Konkret Untuk Meningkatkan Hasil Belajar Matematika Tentang Bangun Datar Pada Siswa Kelas VB SD Negeri 1 Sidoharum Tahun Ajaran 2016/2017. Jurnal Kalam Cendekia Pgsd Kebumen, 5(4.1)

Depdiknas. 2006. Pedoman Penyusunan Kurikulum Tingkat Satuan Pendidikan di Sekolah Dasar. Jakarta: Badan Standar Nasional Pendidikan

Heruman, (2007), Model Pembelajaran Matematika Di Sekolah Dasar, Bandung: PT Remaja Rosdakarya.

Karso, dkk., (2004), Pendidikan Matematika 1, Jakarta: Universitas Terbuka.

Kusmana.S.2010. Model Pembelajaran Siswa Aktif. Jakarta: Sketsa Aksara Lalitya

Krismayeni.P.M.L.(2016).Penerapan Model Pembelajaran Inkuiri Terbimbing Untuk Meningkatkan Keaktifan Dan Hasil Belajar Matematika. Jurnal PGSD Universitas Pendidikan Ganesa,4(1)

Muhsetyo, G., (2014), Pembelajaran Matematika SD, Tangerang Selatan: Universitas Terbuka.

Parti, P., (2016), Meningkatkan Prestasi Belajar Matematika Tentang Pecahan Sederhana Dan Penggunaannya Dalam Pemecahan Masalah Melalui Penggunaan Media Manipulatif. Jurnal Ilmiah Pendidikan dan Pembelajaran Media Didaktika, 2(1)

Sanjaya, W., (2012), Strategi Pembelajaran Berorientasi Standar Proses Pendidikan, Jakarta: Kencana Prenada Media Group.

Trianto, (2007), Model-model Pembelajaran Inovatif Berorientasi Konstruktivistik, Jakarta: Prestasi Pustaka.

Wardhani. I. 2007. Penelitian Tindakan Kelas. Jakarta: Universitas Terbuka 